\title{
Semidiel vertical movements in Atlantic herring Clupea harengus larvae: a mechanism for larval retention?
}

\author{
R. L. Stephenson, M. J. Power \\ Biological Sciences Branch, Department of Fisheries and Oceans, Biological Station, St Andrews, New Brunswick, Canada \\ E0G 2 X0
}

\begin{abstract}
Repetitive, depth-stratified sampling of a patch of herring larvae off southwest Nova Scotia (Bay of Fundy) showed semidiel vertical movement. A $48 \mathrm{~h}$ series of samples taken at $3 \mathrm{~h}$ intervals at 6 or 7 depths indicated a pattern of aggregation near the bottom $(55 \mathrm{~m})$ between $04: 00$ and $07: 00 \mathrm{~h}$ and again at 19:00 to $22: 00 \mathrm{~h}$, but higher in the water $(<30 \mathrm{~m})$ about midday and at 30 to $40 \mathrm{~m}$ about midnight. The pattern was the same for small $(<9 \mathrm{~mm})$ and intermediate (9 to $14 \mathrm{~mm}$ ) larvae, but not for the largest size group (>14 mm) which may have been avoiding the net. The pattern conforms better to a semidiel than to a tidal schedule, but the series is too short to be definitive. Results support the prediction of an active behavioural component to larval retention in herring larvae, but leave open the question of whether vertical movement is being undertaken specifically to affect position or whether retention is the result of vertical movement in relation to other events.
\end{abstract}

\section{INTRODUCTION}

Atlantic herring Clupea harengus spawn demersally in discrete locations to which there appears to be a considerable degree of homing (e.g. Sinclair \& lles 1985). The larval stage is pelagic, and lasts for 3 to 11 mo (Sinclair \& Tremblay 1984). Surveys have shown that larvae remain aggregated, or are retained, in patches of high density for considerable lengths of time; in at least some cases near the spawning area (e.g. Sinclair \& Iles 1985, Chenoweth et al. 1989).

In a recent synthesis on the stock structure of Atlantic herring, Iles \& Sinclair (1982) linked the observation of larval aggregation to stock structure and ultimate stock size. According to this 'larval retention hypothesis' the existence of discrete herring stocks, the location of their respective spawning sites and their relative size are determined by the number, location, and extent of geographically stable retention areas in which the larvae can remain aggregated for the first few months of life (Iles \& Sinclair 1982, Sinclair \& Tremblay 1984, Sinclair \& Iles 1985).

The hypothesis was derived in large part from observations that larval herring in the Bay of Fundy and Gulf of Maine, particularly off southwest Nova Scotia, occur in annually predictable, geographically discrete patches which correspond to spawning areas and which persist for several months. Iles \& Sinclair (1982) pointed to a coincidence with physical conditions specifically well-mixed zones and fronts as defined by the Simpson-Hunter stratification parameter (Simpson \& Hunter 1974) - and argued that such hydrographic features provide the physical basis for retention and act as a focus for the homing instinct of adult herring. They noted that patches of larvae persist in spite of residual current flow through the area, and hypothesized an active behavioural mechanism to affect retention. More recently, Sinclair \& Tremblay (1984) and Sinclair \& Iles (1985) elaborated upon the hypothesis arguing that larvae are retained not passively by the circulation features of the larval retention area, but rather by an active behavioural response by the larvae to the physical regime. They infer that larvae maintain discrete distributions in relation to fixed geographical locations by migrating vertically, thus taking advantage of depth differences in current speed and direction. This view challenges the traditional concept of larval drift, and has led to considerable debate in the literature (e.g. Iles \& Sochasky 1985, Cushing 1986).

Persistence of aggregations of herring larvae on the scale of months has been observed elsewhere, both in estuarine and coastal waters (Graham 1972, 1982, 
Grainger 1980, Fortier \& Leggett 1982, Henri et al. 1985) and offshore, on Georges Bank (Boyar et al. 1973, Bolz \& Lough 1984). Vertical movement (migration) has been noted many times (see reviews by Graham \& Sampson 1982, Fortier \& Leggett 1983), but with different attributed causes and correlates. The active mechanism for larval retention proposed by Sinclair \& Iles (vertical movements in relation to the tidal circulation and/or residual flow) has been inferred in estuarine situations (Graham 1972, Fortier \& Leggett 1982, Henri et al. 1985) but has not yet been observed in 'offshore' areas. Importantly, it has not been documented in the Bay of Fundy/southwest Nova Scotia area which formed the focus for development of the larval retention hypothesis.

In this paper, we present the results of a study designed to test for an active behavioural mechanism as postulated by Iles \& Sinclair (1982). Do herring larvae move (migrate) vertically; and if so, is it to affect position and/or can it be shown to be an effective mechanism for retention? To test this hypothesis we undertook repetitive, depth-stratified sampling at a single site within the annual aggregation of herring larvae off southwest Nova Scotia. This is the largest and best defined of the larval patches in the Bay of Fundy/Gulf of Maine, and includes major spawning areas (particularly Trinity Ledge) of the large southwest Nova Scotia 4WX herring stock. This stock is estimated to be in the order of $500000 t$ in size, and supports the largest herring fishery in the northwest Atlantic with a total annual catch in excess of $100000 \mathrm{t}$ (Stephenson et al. 1987). As well as being fundamental to the larval retention hypothesis, the question of vertical distribution of larvae is of practical importance in its implications for standard spatial surveys using bongo nets (i.e. the standard ICNAF methodology; Anonymous 1972) including the use of this information to estimate population size in stock assessments (Iles et al. 1985, Stephenson et al. 1987).

\section{METHODS}

Field sampling. The results presented in this paper are from 2 cruises undertaken simultaneously in late October and early November, 1985.

A synoptic spatial survey of 150 stations in the Bay of Fundy and eastern Gulf of Maine (EE 'Prince' Cruise 329: 22 Oct to 13 Nov 1985; Fig. 1) was used to define the areal distribution of Iarval herring abundance. At each station, paired $61 \mathrm{~cm}$ bongo nets (0.505 mm mesh, each equipped with a Model 2030 General Oceanics flowmeter mounted in the mouth), were fished in a multiple oblique ('sawtooth') pattern from the surface to an estimated $5 \mathrm{~m}$ off the bottom, for

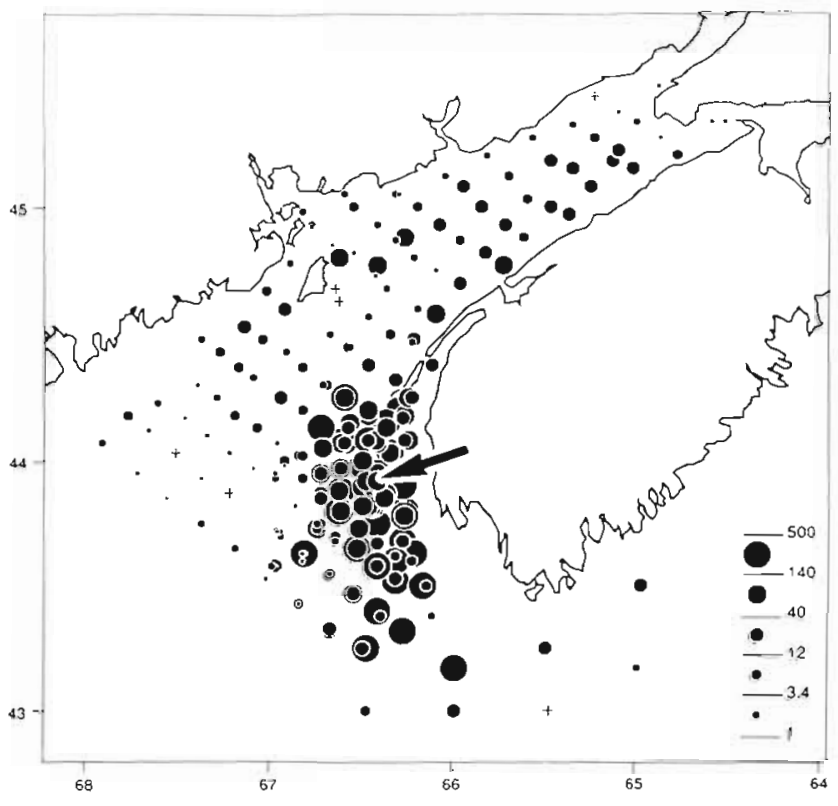

Fig. 1. Clupea harengus larvae. Density (number $\mathrm{m}^{-2}$ ) from a synoptic spatial survey using bongo nets (EE 'Prince' Cruise 329 ) between 22 Oct and 13 Nov 1985. Arrow marks position

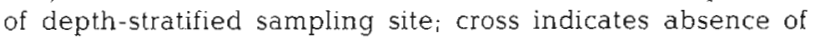
larvae

a minimum tow retrieval of $10 \mathrm{~min}$, at a ship speed of 3.5 knots. Temperature and salinity were measured from samples taken at the surface and bottom, at each station.

At the same time, a site-specific study was undertaken within the larval herring aggregation off southwest Nova Scotia ('Lady Hammond' Cruise 145: 7 to 13 Nov 1985). Sampling focused on a station at $60 \mathrm{~m}$ depth of high larval herring density $\left(43^{\circ} 55^{\prime} \mathrm{N}, 66^{\circ} 25^{\prime} \mathrm{W}\right.$; Fig. 1) and featured a $48 \mathrm{~h}$ series of samples taken at ca $3 \mathrm{~h}$ intervals between 10:00 h on 8 Nov and 10:00 h on 10 Nov. Each set on this cruise included an oblique bongo tow using the same protocol as outlined above for the EE 'Prince' survey, except that one net was $0.505 \mathrm{~mm}$ mesh and the other was $0.333 \mathrm{~mm}$, and that gear depth was monitored by means of a Guildline CTD attached to the bongo. In addition, discrete-depth sampling was undertaken using the MININESS (Reid et al. 1987) with a square mouth area of $0.25 \mathrm{~m}^{2}$ and equipped with 9 nets of $0.333 \mathrm{~mm}$ mesh. Using this sampler, ichthyoplankton was collected at $6(5,10,20$, $30,40,50 \mathrm{~m}$ ) or 7 (additional sample at $55 \mathrm{~m}$ ) discrete depths from the bottom to the surface with a tow duration of $10 \mathrm{~min}$ at each stratum at a speed of 3.5 knots. Depth, temperature and salinjty were monitored continuously by means of a Guildline CTD and depth was adjusted as required. Filtration was recorded using Model 2031 General Oceanics electronic flowmeters. 
Prior to each set, a vertical hydrographic profile was taken using a Guildline CTD system, backed up by water samples from a rosette sampler for salinity calibration.

All plankton samples were preserved immediately in $5 \%$ buffered formalin. Herring larvae were sorted, identified and measured to the nearest $\mathrm{mm}$ in the laboratory within 3 mo of collection.

In an attempt to account for movement of the water within the larval herring patch at the time of sampling, a satellite-tracked Hermes drifter, with a drogue at $10 \mathrm{~m}$, was released for $24 \mathrm{~h}$ from the study site.

Analyses. Larval densities are expressed as numbers per $\mathrm{m}^{3}$ filtered in bongo tows and in each stratum of the MININESS tows. Vertical distribution of larvae is expressed as the depth stratum containing the maximum number of larvae per $\mathrm{m}^{3}$ per tow, and as the mean centre of mass (ZCM) calculated (as in Fortier \& Leggett 1983) as follows:

$$
\mathrm{ZCM}=\sum_{i=1}^{x} p_{i} z_{i}
$$

where $p_{i}=$ the proportion of larvae (for a particular set) occurring at depth $i ; z_{i}=$ sample depth (m).

To test for relationships between herring distribution and tide we used tidal parameters predicted for the study site $\left(43^{\circ} 55^{\prime} \mathrm{N}, 66^{\circ} 25^{\prime} \mathrm{W}\right)$ by Greenberg's (1983) model. The model is a non-linear, 2-dimensional scheme with a grid size of ca $7 \mathrm{~km}$ (see also Loder \& Greenberg 1986). The model was used to predict vectors representing averaged values for the major M2 portion of the tide, referenced in time to the tide cycle predicted in tables for Yarmouth, Nova Scotia.

\section{RESULTS}

\section{Spatial distribution of larvae}

The spatial distribution of larval herring in the Bay of Fundy and eastern Gulf of Maine has been documented in October/November each year for more than a decade (Iles et al. 1985). Results of the 1985 synoptic spatial survey (Fig. 1) showed the same dense aggregation of larvae off southwest Nova Scotia and into the southern Bay of Fundy which has typified previously surveys. The results showed that the larval patch was at least $9000 \mathrm{~km}^{2}$ in area. Larval densities as high as $10.25 \mathrm{~m}^{-3}$ were recorded, and the patch is estimated (product of site density and area) to have contained at least $5.8 \times 10^{10}$ larvae. The survey confirmed that the site chosen for depth stratified sampling was situated well within this annually occurring larval aggregation (Fig. 1).

\section{Vertical distribution of larvae}

Depth-stratified sampling spanned $6 \mathrm{~d}$, but was concentrated in a $48 \mathrm{~h}$ period beginning 09:00 h on 8 Nov. Overall density of herring larvae at the study site (determined from oblique bongo tows) was high, ranging from 0.27 to 1.20 larvae $\mathrm{m}^{-3}$ over the entire sampling period, and averaging $0.58 \pm 0.32 \mathrm{SD}$ during the 48 h series (Table 1 ).

Depth-stratified sampling showed that herring larvae were not distributed uniformly throughout the water column (Table 1). Densities in individual strata of a single sample ranged as much as 0.04 to 8.96 larvae $\mathrm{m}^{-3}$ (50 $\mathrm{m}$ and $5 \mathrm{~m}, 13: 00 \mathrm{~h}$ on 7 Nov) and in most sets there was an obvious aggregation of larvae at one depth. Further, the depth at which herring larvae were aggregated varied over time (Table 1). Depth of maximum density ranged from $5 \mathrm{~m}(13: 00 \mathrm{~h}$ on 7 Nov) to $55 \mathrm{~m}$ (several sample times); the center of mass (ZCM) ranged from $8.7 \mathrm{~m}(13: 00 \mathrm{~h}$ on $7 \mathrm{Nov})$ to $47.5 \mathrm{~m}(19: 00 \mathrm{~h}$ on $8 \mathrm{Nov}$ ).

The temporal variation in depth distribution (measured as either ZCM or depth of maximum abundance) conformed to a semidiel pattern. Fig. 2 shows that there seems to be a general pattern of larval aggregation near the bottom at 04:00 to $07: 00 \mathrm{~h}$ and again at 19:00

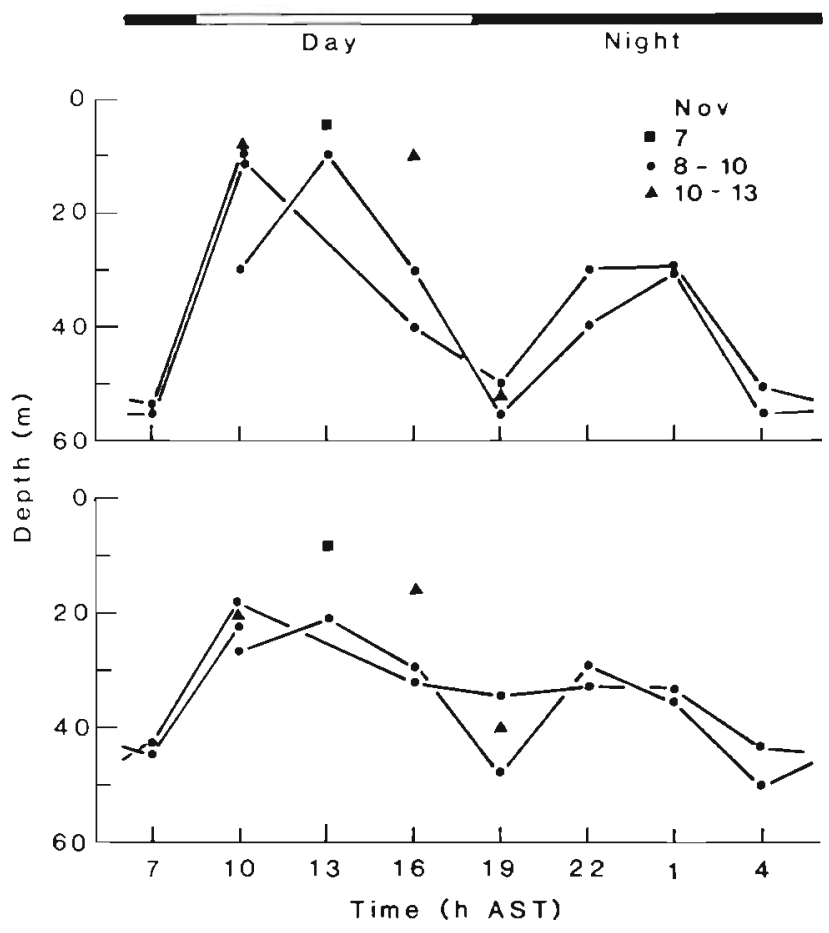

Fig. 2. Clupea harengus larvae. Depth of maximum concentration (upper) and depth of centre of mass, ZCM (lower) against sampling hour (local Atlantic standard time) for MININESS samples taken 7 to 13 Nov 1985 at $43^{\circ} 55^{\prime}$ N, $66^{\circ} 25^{\prime} \mathrm{W}$. Results from adjacent samples of the $48 \mathrm{~h}$ series are joined by lines 


\begin{tabular}{|c|c|c|c|}
\hline \begin{tabular}{l}
3 \\
$\dot{0}$ \\
$m$ \\
\hdashline
\end{tabular} & 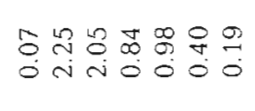 & $\stackrel{\sharp}{0}$ & 号 \\
\hline 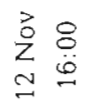 & 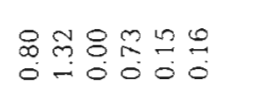 & - & $\begin{array}{l}\mathscr{\infty} \\
\infty \\
\stackrel{\leftrightarrow}{\oplus}\end{array}$ \\
\hline $\begin{array}{l}8 \\
\stackrel{8}{9}\end{array}$ & 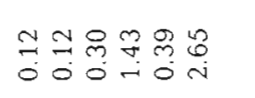 & $\stackrel{5}{0}$ & 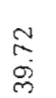 \\
\hline $\begin{array}{l}8 \\
\stackrel{0}{\varrho}\end{array}$ & 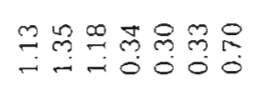 & ले & 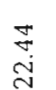 \\
\hline $\begin{array}{ll}0 & 0 \\
2 & 0 \\
0 & 0 \\
0 & 0\end{array}$ & 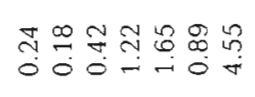 & 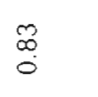 & 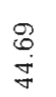 \\
\hline $\begin{array}{l}8 \\
\dot{0}\end{array}$ & 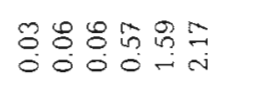 & $\stackrel{8}{8}$ & \begin{tabular}{l}
$\stackrel{8}{6}$ \\
\multirow{\gamma}{*}{}
\end{tabular} \\
\hline$\stackrel{8}{\ddot{0}}$ & 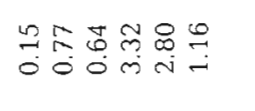 & $\stackrel{ }{\stackrel{2}{\longrightarrow}}$ & $\begin{array}{l}\tilde{\sigma} \\
\text { స్ }\end{array}$ \\
\hline$\underset{\stackrel{\leftrightarrow}{i}}{\stackrel{\sim}{i}}$ & 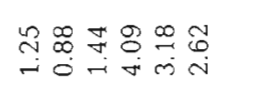 & $\frac{\infty}{0}$ & ले \\
\hline $\begin{array}{l}\stackrel{\circ}{0} \\
\stackrel{\circ}{\circ}\end{array}$ & 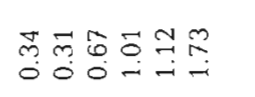 & $\bar{n}$ & $\begin{array}{l}\bullet \\
\stackrel{8}{m} \\
\dot{m}\end{array}$ \\
\hline$\stackrel{8}{\ddot{0}}$ & 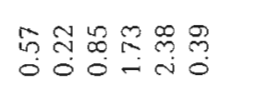 & 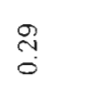 & $\stackrel{m}{2}$ \\
\hline $\begin{array}{ll}\overrightarrow{0} & 8 \\
z & 0 \\
0 & 0\end{array}$ & 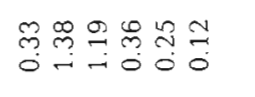 & ì & 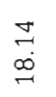 \\
\hline$\underset{8}{8}$ & 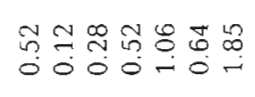 & $\stackrel{\sim}{\tilde{c}}$ & 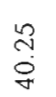 \\
\hline $\begin{array}{l}\mathscr{8} \\
\ddot{0}\end{array}$ & 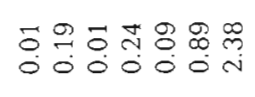 & $\vec{m}$ & $\begin{array}{l}\stackrel{g}{m} \\
g \\
\sigma\end{array}$ \\
\hline$\stackrel{8}{\stackrel{8}{0}}$ & 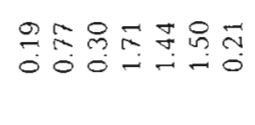 & in & ले \\
\hline$\underset{\stackrel{8}{్}}{\stackrel{N}{N}}$ & 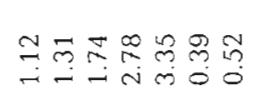 & $\stackrel{\stackrel{g}{=}}{=}$ & 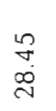 \\
\hline$\stackrel{8}{\circ}$ & 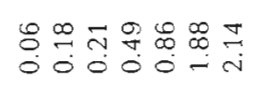 & $\stackrel{3}{0}$ & $\begin{array}{l}\infty \\
\infty \\
\dot{\gamma}\end{array}$ \\
\hline 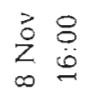 & 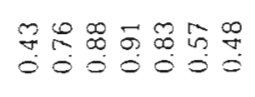 & 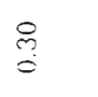 & $\underset{\sigma}{\vec{y}}$ \\
\hline $\begin{array}{l}8 \\
\dot{m}\end{array}$ & 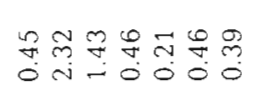 & $\stackrel{m}{n}$ & $\stackrel{\oplus}{\stackrel{\sim}{\sim}}$ \\
\hline$\stackrel{8}{\grave{0}}$ & 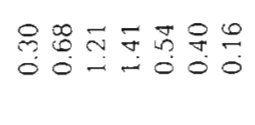 & $\stackrel{\vec{m}}{0}$ & 恣 \\
\hline $\begin{array}{l}o \\
\dot{z} \\
i\end{array}$ & 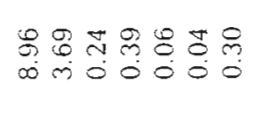 & $\vec{\sigma}$ & $\underset{\infty}{m}$ \\
\hline 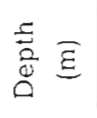 & 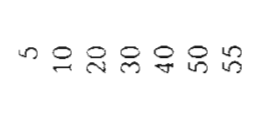 & 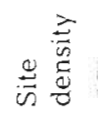 & $\sum_{N}$ \\
\hline
\end{tabular}

to $22: 00 \mathrm{~h}$, but higher in the water (within the top $30 \mathrm{~m}$ ) about midday, and at 30 to $40 \mathrm{~m}$ about midnight. The pattern was the same for small $(<9 \mathrm{~mm})$ and intermediate-size (9 to $14 \mathrm{~mm}$ ) larvae; but not for the largest $(>14 \mathrm{~mm}$ ) size fraction. (Table 2). The abundance of large larvae varied during the $48 \mathrm{~h}$ series with relatively low numbers taken near the surface, particularly during the day.

\section{Hydrography, tide and currents}

The distribution of larval herring off SW Nova Scotia is known to occur within an area of well-mixed water. CTD profiles taken before each set confirmed the vertical homogeneity of the water at the study site. Samples from all depths during the entire $48 \mathrm{~h}$ experiment exhibited a small total range of salinity $=0.47 \%$ ( 32.09 to $32.56)$, of temperature $=0.50 \mathrm{C}^{\circ}(9.10$ to 9.60$)$ and sigma- $\mathrm{T}=0.29$ (24.87 to 25.16$)$. The satellite-tracked drifter deployed at $14: 32 \mathrm{~h}$ on 9 Nov travelled in a NW direction and was recovered $24 \mathrm{~h}$ later $18.45 \mathrm{~km}$ from the point of release (net rate of movement $=0.79$ $\mathrm{km} \mathrm{h}^{-1}$ ). The path of the drifter is consistent with the narrow tidal ellipse, with a north/south axis and maximum tidal velocities in the order of $90 \mathrm{~cm} \mathrm{~s}^{-1}$, predicted from Greenberg's (1983) model (Fig. 3A, B).

\section{DISCUSSION}

\section{Pattern of vertical movement}

Contradictory conclusions have been drawn in the past concerning the diel vertical movement of herring larvae (see reviews by Seliverstov 1974, Lough 1975. Blaxter \& Hunter 1982, Graham \& Sampson 1982). These range from avoidance of surface waters by day and migration upwards at night (Seliverstov 1974, Sameoto 1984), through no clear pattern of movement (Henderson 1987) to higher concentrations in upper waters by day (Wood 1971 [on overcast days]; this study). Sjoblom \& Parmanne (1978) reported a switch in the behaviour of Baltic herring larvae, from a peak abundance in deep water by day early in summer to occurrence close to the surface by day and deeper by night later the same summer. Blaxter \& Hunter (1982) concluded that the general pattern is one of a daytime concentration at a depth somewhere near $20 \mathrm{~m}$ (although with a total range down to $80 \mathrm{~m}$ or more), and a tendency at night to move up but also to become more spread out in terms of depth.

Light (negative phototaxis) has been implicated as a cue in several studies, based upon both field and lab results although it seems in most cases that the 


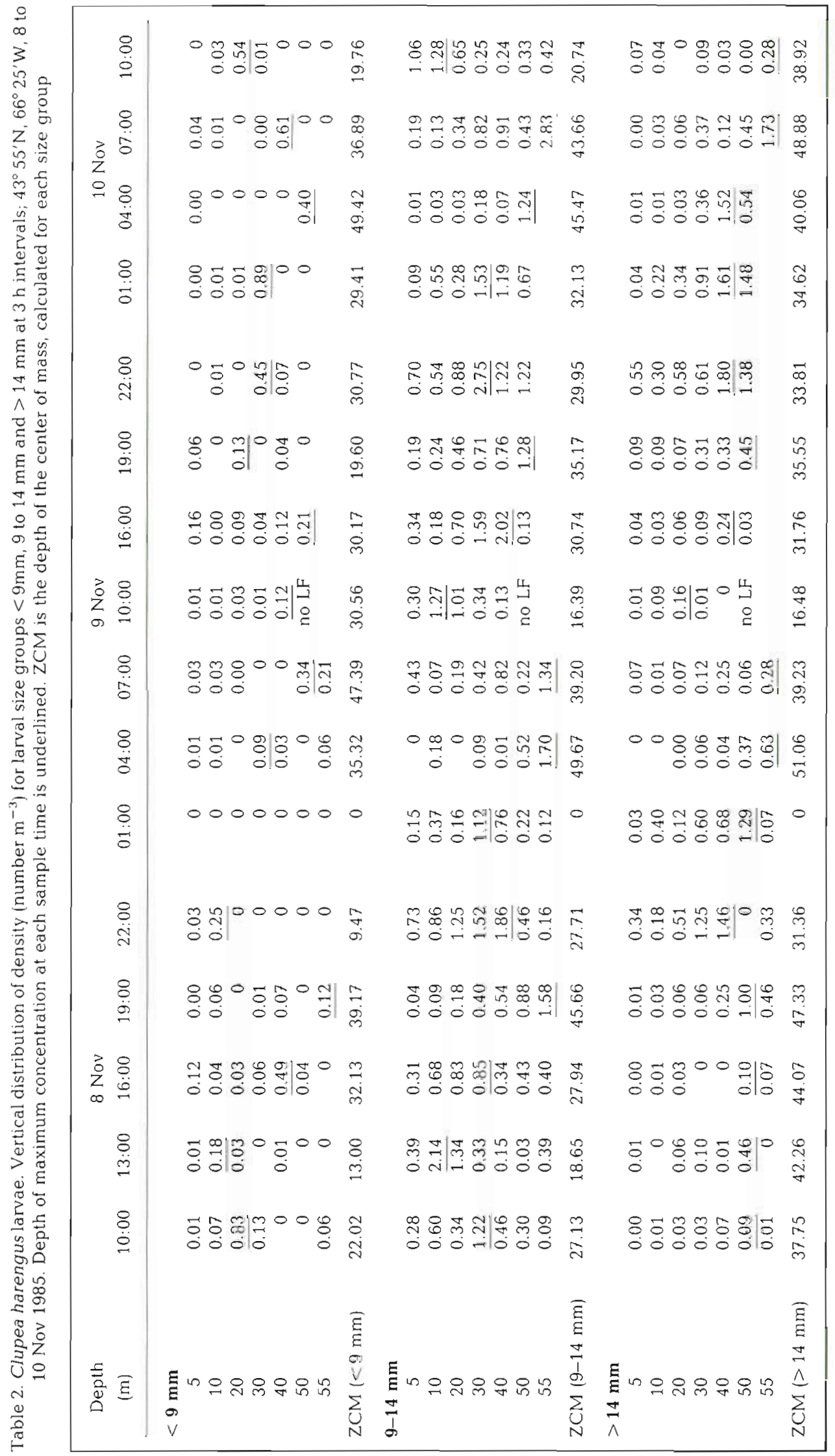



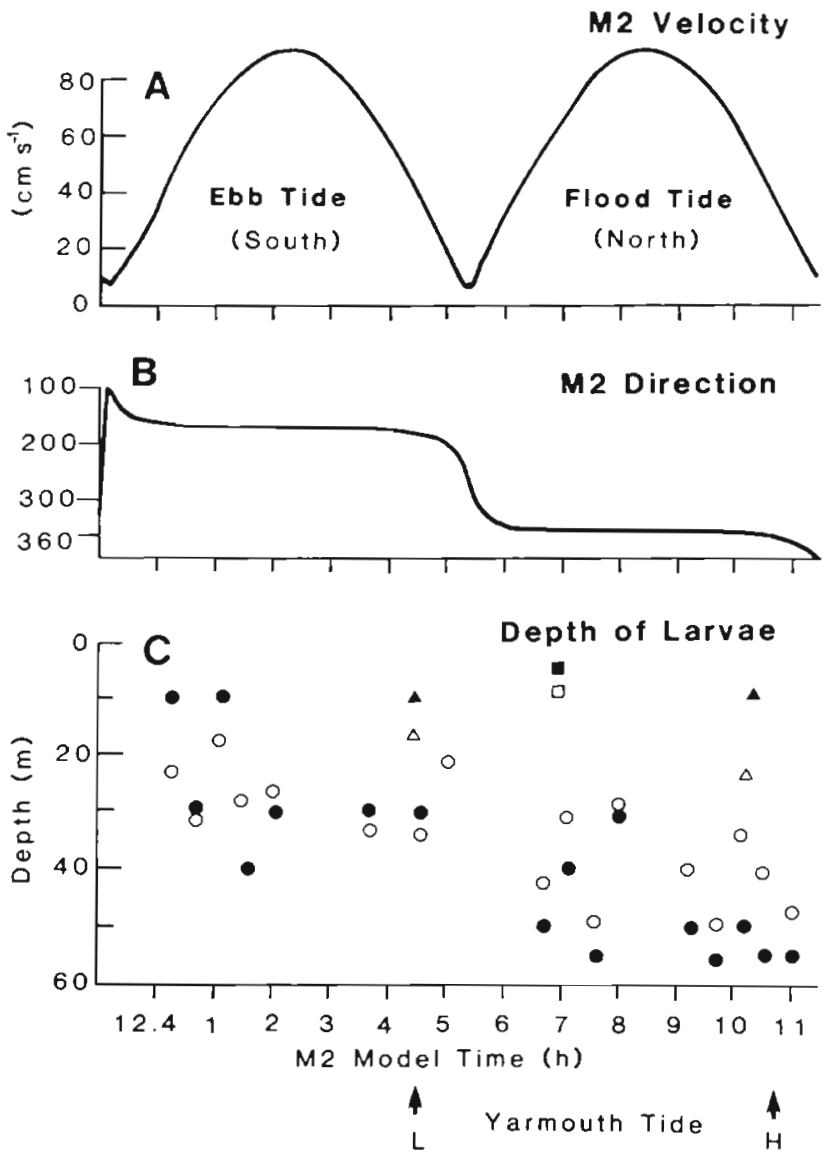

Fig. 3. Plot of the velocity (A) and direction (B) of the M2 tide for the study site predicted by Greenberg's (1983) model, and of the relationship between depth of larval herring aggregation and the M2 tide model time (C). In (C), solid symbols indicate depth of maximum larval concentration; open symbols centre of mass (ZCM) for samples taken 7 Nov (squares), 8 to 10 Nov (circles) and 10 to 13 Nov (triangles)

amplitude of vertical movement is insufficient to maintain a preferendum (see review by Blaxter \& Hunter 1982). Studies involving feeding habits have shown a correlation between larval and prey movement (e.g. Fortier \& Leggett 1983), which may be in response to light. Others, particularly those studying estuaries, have linked vertical movement to currents and maintenance of larvae within the estuary (Graham \& Sampson 1982).

Patterns are complicated further by size-specific differences or changes in larval behaviour with respect to vertical movement. A diel vertical movement is generally thought to develop sometime around $4 \mathrm{~d}$ after hatching, and to become stronger in older larvae (Blaxter \& Hunter 1982).

However, resolution of the pattern of vertical movement of herring larvae in most previous studies has been limited by gear constraints and sampling design; particularly the frequency of sampling and the number of depths sampled. Most have considered only day vs night samples (e.g. Henderson 1987); often by averaging (aggregating) samples for each period. The result, predictably, has been limited to statements concerning the diurnal (day/night) nature of larval herring vertical movement; the frequency of sampling being too low to detect any finer pattern (the importance of this problem for interpretation of vertical migration generally has been pointed out by Pearre 1979). One previous study which did sample with high frequency (sampling interval of $1 \mathrm{~h}$ ) (Fortier \& Leggett 1983) detected a semidiel pattern, but was limited to only 3 depth strata. We present a more frequent temporal series than has been used in recent 'day/night' papers on vertical migration in ichthyoplankton (e.g. Brewer \& Kleppel 1986, Castonguay \& Mcleave 1987) and a vertical series of higher resolution than in Fortier \& Leggett (1983).

Our study indicates a definite semidiel vertical movement of larval herring through as a much as $50 \mathrm{~m}$ (Fig. 2). Depth of maximum concentration of larvae ranged through $50 \mathrm{~m}$ and $Z C M$ through $30 \mathrm{~m}$, in an area with a maximum depth of $60 \mathrm{~m}$. The pattern observed in samples spanning $7 \mathrm{~d}$ in 1985 is one of aggregation at depth (50 to $55 \mathrm{~m}$; near bottom) at 04:00 to $07: 00 \mathrm{~h}$ and again at $19: 00 \mathrm{~h}$, with movement to between 10 and $20 \mathrm{~m}$ during the day $(10: 00$ to $16: 00 \mathrm{~h})$ and to intermediate depths $(30$ to $40 \mathrm{~m})$ at night (22:00 to $01: 00 \mathrm{~h}$ ).

The breakdown of our data by larval size grouping (Table 2 ) indicates that larvae of bath small ( $<9 \mathrm{~mm}$ but post yolk sac) and intermediate ( 9 to $14 \mathrm{~mm}$ ) sizes follow the same pattern. Detection of vertical movement in the smaller size group is in contrast to literature reports that young herring larvae do not move vertically (Seliverstov 1974, Graham \& Sampson 1982, Fortier \& Leggett 1982, 1983). Larvae of the largest size group (>14 mm) were few in number, and appeared to be taken mostly in deeper samples or at night. This indicates either a different pattern of vertical movement by the larger larvae (movement to near bottom, or at least below the lowest net, by dayj or possible avoidance of the sampling gear in surface layers during daylight. Further evidence for the differential capture of large larvae is a detectable decrease in mean length of larvae during daylight compared with night-time bongo samples (Fig, 4). Diel variation in the catches of large larvae has been recorded in previous studies, and attributed to visual detection and avoidance of nets (reviewed by Blaxter \& Holiday 1963).

The greatest concentration of Iarvae occurred in the deepest sample depth twice in the diel series, and raises the question of whether herring larvae move even deeper (i.e. right to bottom). Although a number of authors have suggested that herring larvae do not 


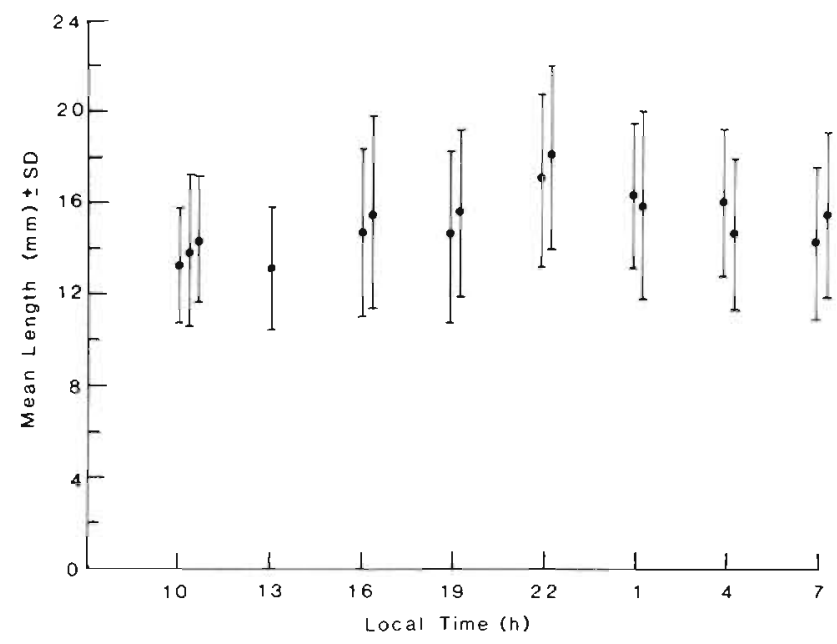

Fig. 4. Clupea harengus larvae. Diel variation in length (mean $\pm S D$ ) taken in repetitive bongo tows $(0.333 \mathrm{~mm}$ mesh) at $43^{\circ} 55^{\prime} \mathrm{N}, 66^{\circ} 25^{\prime} \mathrm{W}$ (off southwest. Nova Scotia, 7 to $13 \mathrm{Nov}$ 1985)

occur near the bottom (Fortier \& Leggett 1983) it is possible that the distribution of larvae extended below the lowest sample depth i.e. within $5 \mathrm{~m}$ of bottom, as concluded also by Sjoblom \& Parmanne (1978; although for a shallower site). Subsequent epibenthic sled samples from the same area (November 1987) showed densities as high as $3 \mathrm{~m}^{-3}$ near the bottom (R. L. Stephenson unpubl.). This point is of critical importance to standard oblique bongo survey protocol in that it would lead to undersampling of larvae in tows which typically do not sample within $5 \mathrm{~m}$ of the bottom. The deepest net of each MININESS tow was $5 \mathrm{~m}$ from the bottom, and gives an indication of the potential error which would occur in an oblique tow which missed this stratum. As high as $62 \%$ of the sum of densities (for all strata) for each tow occurred in the lowest stratum during the $48 \mathrm{~h}$ series of tows (Fig. 5). Further, there appeared to be a diel pattern to the proportion of larvae in this stratum, linked to the semidiel vertical movement. The implication is that there could be a time-dependent bias in sampling larval herring using standard ichthyoplankton methods (e.g. oblique bongo tows). This aspect is being investigated further in a comparison of MININESS and bongo samples and a study using an epibenthic sampling device (Stephenson unpubl.).

\section{Timing of vertical movement}

The semidiel nature of the pattern of vertical movement suggested either a link with time of day (i.e. light) or with tide. Because tidal movement has been suggested as a mechanism accounting for the larval reten-

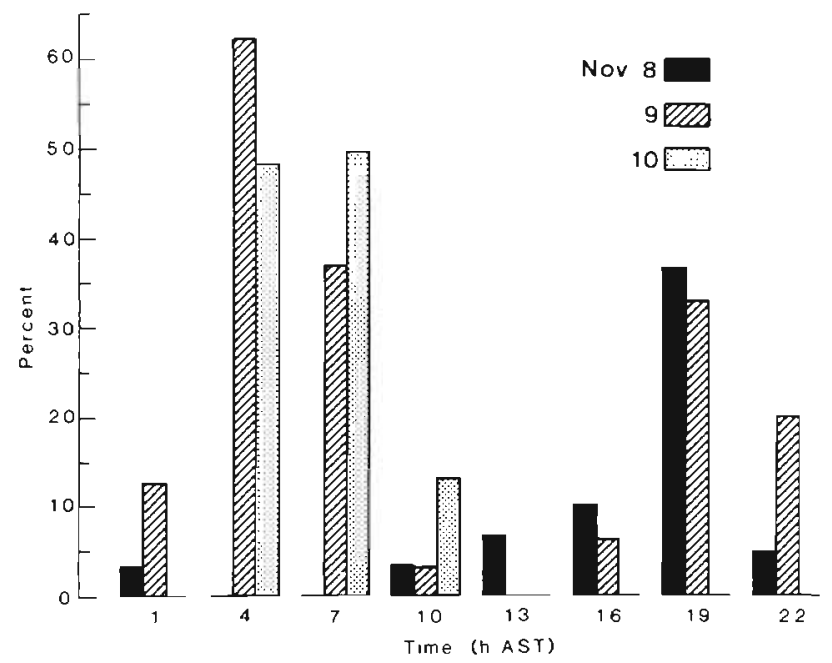

Fig. 5. Diel variation in the proportion (\%) of larval herring caught in the deepest MININESS net over a $48 \mathrm{~h}$ period off southwest Nova Scotia, 8 to 10 Nov 1985

tion phenomenon, we were interested particularly in examining the relationship between vertical movement and tide.

Comparison of the vertical position of larvae during the $48 \mathrm{~h}$ series with the current vector cycle (calculated from Greenberg's 1983 model) of the M2 tide for the study area (Fig. 3) shows some correspondence. The larvae were, generally, highest in the water column during southerly ebb tide, and nearer the bottom during the northerly flow of flood tide (Fig. 3C). Vertical current profiles from a meter mooring site nearby showed a reduction in velocity of tidal currents of at least one third within $10 \mathrm{~m}$ of the bottom (Tee et al. 1987); and bottom drift bottles released near the study site showed a significant difference in direction of movement, in comparison to surface bottles (R. I. Perry, DFO, pers. comm.). The result of the observed pattern of larval movement would be a reduction, or elimination, of the effect of the residual flow to the north indicated by the Hermes drifter. However, on the basis of the $48 \mathrm{~h}$ series alone, we cannot discriminate between a tidal and a true semidiel pattern; during this period the flood tide coincides with pre-dawn and postdusk periods, which may also be crepuscular events of a light-related pattern. The sample period was not long enough to investigate the pattern of larval movement when the tide was at a different phase. Extreme samples from our series ( 7 and 13 Nov) fit the semidiel pattern (Fig. 2) better than the tidal pattern (Fig. 3).

The conformity to a semidiel pattern is consistent with suggestions in the literature linking vertical position of herring larvae in the water column with the changes in the distribution and abundance of prey items (Fortier \& Leggett 1983). This is presumably 
ultimately linked with light (Blaxter 1985) both by its effect on zooplankton and on larval feeding. In that case the pattern would be, more specifically, semidiurnal (as concluded aiso by Fortier \& Leggett 1983). However, the occurrence of larvae higher in the water column during the day is inconsistent with the expected negative phototaxis observed in herring larvae in the lab (Blaxter 1973) and in zooplankton in general (Castonguay \& McCleave 1987). Fortier \& Leggett (1983) demonstrated that the $12.5 \mathrm{~h}$ (i.e. tidal) pattern of vertical movement of herring larvae in the Gulf of St Lawrence coincided with the vertical pattern of microzooplankton (prey) abundance, which they suggested was determined by hydrography.

There is no doubt that vertical movement (migration) is a common behavioural trait of herring larvae: it has now been observed in a range of sizes of herring larvae, in several stocks from disparate geographic locations, and in a range of hydrographic regimes. There is also no doubt that dispersion of herring larvae is not by completely passive drift (in the sense of a neutrally buoyant suspension). Passive drift in this area would result in movement in a northerly direction at a rate of about $19 \mathrm{~km} \mathrm{~d}^{-1}$ (as indicated by the satellite tracked drogue) and, based upon drifter results, into the Bay of Fundy or westward to the coast of Maine with an expected displacement of several hundred $\mathrm{km}$ over 3 mo (Sinclair \& Iles 1985). It is reasonable to assume that vertical movement affects spatial distribution; however, the degree to which vertical movement (migration) is being undertaken to control position is still unclear. Is it, as maintained by Iles (Iles \& Sochasky 1985, pers. Comm.), the result of active behavioural responses by individuals to use the hydrography to achieve and maintain (spatial) position? Or is it a semidiel behavioural pattern related to some other factor (such as light, prey availability, predators) which results in a modified spatial distribution pattern? If the former, it must conform to a tidal schedule. However, the pattern of vertical movement observed in this study is related better to the time of day (Fig. 2) than to the state of the tide (Fig. 3) and indicates the latter It suggests that semidiel vertical movements through most of the $60 \mathrm{~m}$ water column and involving periods of movement to very near bottom, combined with currents in this area, dominated by tide, result in a slow elongation of the larval herring distribution to the north; in the direction of, but very much slower than the residual flow. On the other hand, the variety of patterns of vertical movement observed in other studies indicates that there may be different mechanisms operating in different situations. Iles \& Sochasky (1985) point out that only minor modification ('modulation') of a regular diel behaviour pattern would be sufficient to allow use of currents in different directions.
Acknowledgements. We are indebted to J. G. G. Reid and P. C. F. Hurley for their support of the MININESS system with which the discrete-depth samples were collected. We acknowledge the support of the officers and crew of the 'Lady Hammond' Cruise 145 and EE 'Prince' Crusse 329. We thank Drs R. I. Perry and J. W. Loder for assistance with tidal analysis, and Drs T D. Iles and J. D. Neilson for useful discussions and comments on an earlier version of the manuscript.

\section{LITERATURE CITED}

Anonymous (1972). Working group on joint survey of larval herring in Georges Bank - Gulf of Maine areas (ICNAF Subareas 4X, 5Y and 5Z, 9-12 May 1972). Boothbay Harbor, Maine. Int. Comm. Northwest Atl. Fish. Res. Doc. $72 /$ 123 (Ser. No. 2852), ICNAF, Dartmouth p. 1-39

Blaxter, J. H. S. (1973). Monitoring the vertical movements and light responses of herring and plaice larvae. J. mar. biol. Ass. U.K. 53: 635-647

Blaxter, J. H. S. (1985). The herring: a successful species? Can. J. Fish. Aquat. Sci. Suppl. 42 (1): 21-30

Blaxter, J. H. S., Holliday, F. G. T (1963). The behaviour and physiology of herring and other clupeids. Adv. mar. Biol. 1: 261-393

Blaxter, J. H. S., Hunter, J R. (1982). The biology of the clupeoid fishes. Adv. mar. Biol. 20: 1-223

Bolz, G. R., Lough, R. G. (1984). Retention of ichthyoplankton in the Georges Bank region during the autumn-winter seasons, 1971-77. J. Northwest Atl. Fish. Sci. 5 (1): 33-45

Boyar, H. C., Marak, R. R., Perkins, F. E., Clifford, R. A. (1973). Seasonal distribution and growth of larval herring (Clupea harengus L.) in the Georges Bank - Gulf of Maine area from 1962 to 1970. J. Cons. int. Explor Mer 35: 36-51

Brewer, G. D., Kleppel, G. S. (1986). Diel vertical distribution of fish larvae and their prey in nearshore waters of southern California. Mar. Ecol. Prog. Ser 27: 217-226

Castonguay, M., McCleave, J. D. (1987). Vertical distributions, diel and ontogenetic vertical migrations and net avoidance of leptocephali of Anguilla and other common species in the Sargasso Sea. J. Plankton Res. 9: 195-214

Chenoweth, S. B., Stephenson, R. L., Power, M. J., Libby, D. A. (1989). Origin and dispersion of larval herring (Clupea harengus L.) in coastal waters of eastern Maine and southwestern New Brunswick. Can. J. Fish. Aquat. Sci. (in press)

Cushing, D. H. (1986). The migration of larval and juvenile fish from spawning ground to nursery ground. J. Cons. int. Explor. Mer 43: 43-49

Fortiel, L., Leggett, W C. (1982). Fickian transpurt and the dispersal of fish larvae in estuaries. Can. J. Fish. Aquat. Sci. $39(8):$ : $1150-1163$

Fortier, L., Leggett, W. C. (1983). Vertical migrations and transport of larval fish in a partially mixed estuary. Can. J. Fish. Aquat. Sci. 40 (10): 1543-1555

Graham, J. J. (1972). Retention of larval herring within the Sheepscot Estuary of Maine. US Nat. Mar. Fish. Serv. Fish Bull. 70: 299-305

Graham, J. J. (1982). Production of larval herring, Clupea harengus, along the Mainn coast, 1964-78. J. Northwest Atl. Fish Sci. 3: 63-85

Graham, J. J., Sampson, D. B. (1982). An experiment on factors affecting depth distribution of larval herring. Clupea harengus, in coastal Maine. Northwest Atl. Fish. Organ. Sci. Counc. Stud. (3): 33-38 
Grainger, R. J. R. (1980). The distribution and abundance of herring larvae to the south of Ireland in 1979/80. Int. Counc. Explor. Sea Comm. Meet. 1980 (H49): 1-14

Greenberg, D. A. (1983). Modeling the mean barotropic circulation in the Bay of Fundy and Gulf of Maine. J. phys Oceanogr. 13 (5): 886-904

Henderson, P. A. (1987). The vertical and transverse distribution of larval herring in the River Blackwater estuary, Essex. J. Fish Biol. 31 281-290

Henri, M., Dodson, J. J., Powles, H. (1985). Spatial configurations of young herring (Clupea harengus harengus) larvae in the St Lawrence estuary: importance of biological and physical factors. Can. J. Fish. Aquat. Sci. Suppl. 42 (1): 91-104

Iles, T D., Power, M. J., Stephenson, R. L. (1985). Evaluation of the use of larval survey data to tune herring stock assessments in the Bay of Fundy / Gulf of Maine. Northwest Atl. Fish. Organ. Sci. Counc. Res. Doc. No. 85/107: $1-16$

Iles, T. D., Sinclair, M. (1982). Atlantic herring: stock discreteness and abundance. Science 215: 627-633

Iles, T. D., Sochasky, J. B. (1985). Drift and current selection, transport and retention, dispersal and homing; a review of concept and principles relevant to the temporal and spatial organization of marine systems. Int. Counc. Explor. Sea Comm. Meet. 1985 (L14): 1-18

Loder, J. W., Greenberg, D. A. (1986). Predicted positions of tidal fronts in the Gulf of Maine region. Cont. Shelf. Res. 6 (3): $397-414$

Lough, R. G. (1975). A preliminary report of the vertical distribution of herring larvae on Georges Bank. Int. Comm. Northwest Atl. Fish. Res. Doc. No. $75 / 50$ (Ser. No. 3529): $1-9$

Pearre, S., Jr (1979). Problems of detection and interpretation of vertical migration. J. Plankton Res. 1: 29-44
Reid, J. G. G., Hurley, P. C. F., O'Boyle, R. N. (1987). Mininess: a self-trimming multiple opening and closing plankton net frame design. Proc. IEEE, Oceans 87. Halifax N.S.. $466-471$

Sameoto, D. D. (1984). Environmental factors influencing diuxnal distribution of zooplankton and icthyoplankton. J. Plankton Res. 6: 767-792

Seliverstov, A. S. (1974). Vertical migrations of larvae of the Atlanto-Scandian herring (Clupea harengus L.). In: Blaxter, J. H. S. (ed.) The early life history of fish. Springer Verlag, New York, p. 253-262

Simpson, J. H., Hunter, J. R. (1974). Fronts in the Irish Sea. Nature, Lond. 250: 404-406

Sinclair, M, Iles, T. D. (1985). Atlantic herring /Clupea harengus) distributions in the Gulf of Maine - Scotian Shelf area in relation to oceanographic features. Can. J. Fish. Aquat. Sci. 42 (5): 880-887

Sinclair, M., Tremblay, M. J. (1984). Timing of spawning of Atlantic herring (Clupea harengus harengus) populations and the match-mismatch theory. Can. J. Fish. Aquat. Sci. 41: $1055-1065$

Sjoblom, V., Parmanne, R. (1978). The vertical distribution of Baltic herring larvae (Clupea harengus L.) in the Gulf of Finland. Finn. Fish. Res. 2: 5-18

Stephenson, R. L., Power, M. J., Iles, T. D. (1987). Assessment of the 19864 WX herring fishery. Can. Atl. Fish. Sci. Advis. Comm. Res. Doc. No. 87/75: 1-39

Tee, K. T., Smith, P. C., LeFaivre, D. (1987). Modelling and observations of the residual current off southwest Nova Scotia. In: Nihoul, J. C. J., Jamert, B. M. (eds.) Three dimensional models of marine and estuarine dynamics Elsevier, Amsterdam, p. 455-470

Wood, R. J. (1971). Some observations on the vertical distribution of herring larvae. Rapp. P.-v. Réun. Cons. int. Explor. Mer 160: 60-64

This article was presented by Dr D. J. Wildish; it was accepted for printing on September 8,1988 